\title{
Governor Grimes Wins Senatorship
}

\author{
By L. D. Ingersoll *
}

The first session of the Iowa General Assembly after adoption of the Constitution of 1857 convened at Des Moines in January, 1858. One of the duties of this Assembly was to elect a senator of the United States in place of Gen. George W. Jones, whose term would expire March 3, 1859. The Republicans had elected a good majority of the legislature, and it was known of course that General Jones would have to step down and out. It was also known that about ninety-nine Republicans out of a hundred in the state wanted Governor Grimes to succeed him, but there were several small sets of politicians who each wanted their man elected, and they managed to get up a great deal of noise at Des Moines and to make a lively fight all around. Some of these men even thought they were going to beat Mr. Grimes, but he and his friends knew better all the time and were as serene and happy as big sunflowers.

It was an unusually able assembly. The venerable Steven B. Shelledy, of Jasper, was elected Speaker of the House, beating Hon. Lincoln Clark, of Dubuque, a very strong man in talents and of the highest personal character. A colleague of Mr. Clark was Dennis A. Mahoney, well known as a journalist and politician. Mahoney was a man not only of considerable ability and large intelligence, but a man of convictions. What he believed in he believed in with all his might, and had the habit of expressing his views with much emphasis. This habit afterwards got him into a little unpleasantness with the general government and caused his confinement at old Capitol prison.

Another very active and prominent member of the house on the Democratic side was William W. Belknap, of Lee. He had been in the state about six years, and

- Mss. of Iowa newspaperman writing from Washington, D.C., in 1878. From Iowa State Department of History and Archives, Des Moines. 
had gained considerable reputation as a lawyer. He was of commanding presence, and had good abilities as a forensic orator. He was, in short, a leader on the Democratic side. Martin Van Buren Bennett and I. C. Curtis represented Marion county. They were the very worst Democrats in the business, and Van Bennett was by a large majority the most profuse and windy orator who ever set men crazy.

If there were several strong men among the Democrats, there were several stronger among the Republicans. James F. Wilson represented Jefferson county and was a recognized leader, but in running debates and on "field days" Hon. W. H. Seevers, of Mahaska county (since Supreme Judge and known to everbody in the state) generally was counted as the champion Republican. It was in this house that Ed. Wright and B. F. Gue commenced their public careers. Another young man, then first prominent in the affairs of the state was Thomas Drummond. Tall, straight as an arrow, dark complexioned as a Malay, with eyes and hair black as pitch, this descendant of Pocahontas and son of a sedate Methodist clergyman was the fiery Hotspur of the house and the leader of the Republicans in the opposition to Mr. Grimes.

Poor Drummond! I never think of him without a tear of sympathy. Two years later he served in the senate, taking a very prominent part in the debates and exercising much influence. On the breaking out of the war, Fitz Henry Warren procured him the appointment of captain of cavalry in the regular army, and he served with great distinction. For a considerable period he was Lieutenant-Colonel of the Fourth Iowa Cavalry, but not being able to agree with the easy-going Colonel Porter, he resigned and returned to his regular command. In the very last engagement of the army under Grant, he was mortally wounded while fighting in Sheridan's command. He was borne to the hospital and placed upon a cot. In full consciousness he uttered the words "dulce et decorum est pro patria more,"-"it is sweet and 
worthy to die for one's country"-and immediately expired.

\section{ONE of IowA's ABLEST}

The youngest member of the house, but who nevertheless ranked very high as a debater and as a man of political sagacity beyond his years was a youth from Lee county, since one of the most distinguished statesmen of the country. It was in this house that George W. McCrary, then only 22 years of age, began his political career.

M. M. Trumbull was also there, and Limri Streeter ("Old Black Hawk"), and John Edwards and Lauren Dewey and I forget who all, since more or less distinguished. But I do not forget a man, who later covered himself with renewed glory by making one of the bravest and best canvasses ever conducted, C. C: Carpenter, of Webster. He, too, here entered upon a public career which has been most honorable and distinguished.

The senate was very strong in able men. Among the Democrats were David S. Wilson, H. H. Trimble, W. H. M. Pusey, J. E. Neal and A. O. Patterson; while among the Republicans were such men as Samuel J. Kirkwood, N. J. Rusch, J. B. Grinnell, Alvin Saunders, John W. Rankin, Lyman Cook, William Loughridge, Daniel Anderson, Dr. Davis, J. W. Cattell and Charles Foster.

The Secretary of this senate was George E. Spencer, now and for some years United States senator from Alabama.

This is a "mere muster-roll of names," I admit, but they are the names of big men, whose simple mention will recall a world of varied associations to the old residents of Iowa.

These were the more prominent men of the legislature, by whom the senatorial contest was to be decided. Some of those opposed to Mr. Grimes were in favor of Mr. Bissell, of Dubuque, some of William Penn Clarke, of Iowa City, others of General Warren. These opponents of Grimes finally settled down on Bissell as the winning man. 
There was a big lobby. It was very active and aggressive. The only man in the legislature, however, who made an aggressive war on Grimes was Drummond. $\mathrm{He}$ poured forth on the governor the vials of his impetuous wrath on all occasions. Others of the lobby as Penn Clarke and Hawkins Taylor, rather sneered at Grimes than boldly assailed him. All was of no use, however. When the caucus met, Grimes carried the day so completely that the opposition was hardly worth counting. On the election in joint convention, every Republican voted for him, giving him 64 votes. The Democrats sustained Ben M. Samuels, of Dubuque, who had been beaten in October by $\mathrm{Mr}$. Lowe for governor.

\section{Grimes Reserved in Manner}

Following Mr. Grimes' distinguished service as governor of Iowa, his later public career in the United States senate further demonstrated his preeminent greatness among the public men of his state, although he has been strangely misunderstood and even misrepresented at times. His outward manner to strangers had not always been cordial and he has been. considered in some quarters as having a rough, cold and bearish nature. Undoubtedly, his reserve repelled many persons who should have been drawn to him, but this defect of his arose not from haughtiness or churlishness of disposition but from a certain diffidence as to his own power to say and do just the right thing. This peculiar modesty in Mr. Grimes I have never observed in any other great man. Then he was undoubtedly most outspoken.

In company with a friend from Iowa, I once called on him one night during the Civil war, when the Federal army had met some rebuffs. After the usual salutation I saw he was not feeling well-I said, "I trust, Mr. Senator, you are in excellent spirits tonight?" "No! I am not!" he thundered, "I am as ugly as a Polar bear. Everything is going to the dogs, and I don't see that congress can do any good by staying in this mud-hole town!" I suggested that he needn't get off his Polar bear business on me, and with a jolly remark about tak- 
ing a ride to Bladensburg, got him into good humor, and we had one of the finest evenings men ever enjoyed. Mr. Fessenden came in presently-cross as a bear, too -and Grimes got him in fine spirits, and the talk was splendid.

On our leaving, my friend said that his opinion of Grimes had undergone a complete revolution. He had always believed him to be a rough, churlish man, but found him to be a gentleman of wonderfully versatile and fascinating conversational powers. Thus it always happened with men who really got at the senator; who knew how to crack the shell and get the kernel. $\mathrm{He}$ was a warm-hearted philanthropist whose charities were much greater than have ever been publicly known. In his friendship he was as true as steel. As statesman and man he had as many great and as few ill qualities as are commonly allowed to human nature.

\section{"Such Is Greatness"}

The manuscript files of the Iowa Department of History contain the correspondence of the state's great men. Researchers frequently uncover letters that occasion merriment as well as those of historic importance. One of the former was recently revealed, written by L. M. Shaw, Secretary of Treasury in Pres. Theodore Roosevelt's cabinet and former governor of Iowa, to Gov. Albert B. Cummins, his successor, that will still have interest for Iowans. It reads:

TREASUTY DEPARTMENT

Office of the Secretary

Washington, March 19, 1902

Dear Mr. Cummins:

I enclose herewith a letter from Mrs. Clara Miller Wheeler for consideration and reply, and incidentally for the solution of the joke connected with its transmission to me. Strange, is it not, that she should never have heard that you had become Governor, or I Secretary? Such is greatness. I join in mutual commiseration. Hon. Albert B. Cummins Very truly yours, Governor of Iowa (Signed) L. M. Shaw

Des Moines, Iowa. 
Copyright of Annals of Iowa is the property of State of Iowa, by \& through the State Historical Society of Iowa and its content may not be copied or emailed to multiple sites or posted to a listserv without the copyright holder's express written permission. However, users may print, download, or email articles for individual use. 